\title{
Overcoming Methodological Nationalism in Nationalism Studies: The Impact of Tourism on the Construction and Diffusion of National and Regional Identities
}

\author{
Post-print \\ Original published in: \\ History Compass 12/4 (April 2014) 361-373 \\ See also: DOI: $10.1111 /$ hic3.12141 or \\ http://onlinelibrary.wiley.com/doi/10.1111/hic3.12141/abstract
}

\author{
Eric Storm \\ Institute for History \\ Leiden University
}

\begin{abstract}
During the last thirty years, our understanding of the nation-building process in various parts of Europe and across the globe has increased substantially. Some of the most important results of this growing body of studies will be discussed in this review article, which consists of four parts. First, I will examine some innovative trends in the field of nationalism studies, such as the growing attention for the impact of nationalism on popular culture and the interplay between regional and national identities. The second part makes clear that the overwhelming majority of existing studies deals with one region or nation, while taking the national framework for granted. By presenting the history of Europe as a collection of (isolated) national histories, most scholars still fall prey to a methodological nationalism. One way to overcome this (implicit) methodological nationalism is to analyse the impact of foreign tourism on the construction and diffusion of national and regional identities. The role of tourism in the construction of territorial identities has already been explored in a growing number of studies. Some of the most important contributions to this field will be reviewed in the third part. Finally, I will argue that the impact of foreign visitors on the nation-building process can best be studied in a comparative way by focusing on local communities as the arena in which the outside influences of an international, national and regional level came together and demanded a local response.
\end{abstract}




\section{Overcoming Methodological Nationalism in Nationalism Studies: The Impact of Tourism on the Construction and Diffusion of National and Regional Identities ${ }^{1}$}

Over the last three decades, the study of nationalism and the construction and diffusion of national identities has changed considerably. Thousands of academic books and articles have greatly enriched our understanding of the nation-building process in various parts of Europe and around the globe. However, the overwhelming majority of investigations still consist of case studies that deal with one particular aspect of this process within a specific local, regional or national context. As a result, the national framework is still taken for granted. At the same time, most studies are thoroughly embedded within national historiographical traditions. In fact, one could argue that the field of nationalism studies has not been denationalised itself and that most investigations still implicitly adhere to a largely unconscious methodological nationalism.

In this article, I will present a brief overview of the main developments within the field of nationalism studies, after which I will argue that analysing the impact of tourism on the construction and diffusion of national and regional identities can be a good way to overcome the implicit methodological nationalism of existing publications. Although occasionally I will refer to studies on Eastern Europe, the United States and the non-Western world, the focus will be on Western Europe during the nineteenth and early twentieth centuries.

\section{The modernist consensus}

The study of nationalism and the construction and diffusion of national identities received a major boost in 1983 when three ground-breaking books were published by Ernest Gellner, Benedict Anderson and Eric Hobsbawm. ${ }^{2}$ They all saw nations and nationalism as inherently modern, their rise being intimately related to the emergence of modern, industrial and secular society. Although these British scholars developed their own interpretations, they essentially argued that the new 'imagined communities' based on a shared standard language and an accompanying high culture were the consequence of the rise of (print-) capitalism and the subsequent need of (mass-) education. Therefore, national identities had to be assembled, constructed or even invented, each with its own heroes, glorious past, monuments, patrimony and idiosyncratic character. These modernist interpretations have been strongly criticised by scholars such as Anthony D. Smith and specialists of early modern history, who argue that while modern nation-states may differ substantially from earlier states, in most cases their national identities have strong roots in older ethnic identities. ${ }^{3}$ Nonetheless, the ideas espoused by Gellner, Anderson and Hobsbawm have greatly influenced the rapidly growing body of studies on nationalism, national identities and nation-building. ${ }^{4}$

Since most scholars accepted the modernist interpretation of nationalism, arguing that national identities are constructed or even invented, they obviously focused their attention on those who created the heroes, history and identity of a nation, or those who defined its patrimony, its typical landscapes, monuments and traditions. As a consequence, most studies of nationalism in the last few decades deal with politicians, intellectuals, writers, journalists, painters, sculptors, architects and museum directors, and with the often fierce debates between these political and intellectual elites on the correct interpretation of the nation's identity in political forums, associations and the press. However, not only the construction of national identities has been studied; the same is true for the diffusion of the new national awareness, the nation-building process and the 'nationalisation of the masses'. Already in 1976, Eugen Weber's Peasants into Frenchmen showed how French peasants were thoroughly 'nationalised' by the opening up of local markets, the rapid extension of infrastructure, the 
growing role of the state and the national political sphere, and above all through schooling and military service. ${ }^{5}$ As a result, many historians began to examine the role of the state in promoting a greater national awareness. Thus, the impact of military service, education particularly instruction in the (national) language, history and geography - and the growth in infrastructure on the nation-building process has been intensively scrutinised. ${ }^{6}$ In brief, in both types of studies the focus has been on the activities of the political, administrative and intellectual elites within a specific country or national movement.

The preference for a top-down approach is also understandable for practical reasons. On the one hand, the elites have left innumerable traces of their activities and public debates, which can easily be consulted in archives and libraries. On the other hand, it is extremely difficult to analyse the reactions of millions of ordinary citizens who participated in national celebrations, visited museums, studied their national history and became socialised in a national standard language. One could study diaries, letters and other private documents, but in general it is difficult to locate a representative sample of such documents and often those documents obtained do not provide many interesting insights. ${ }^{7}$

A new promising approach in this respect is the study of 'banal nationalism', defined by Michael Billig in his seminal book published in 1995. According to him, national identities are strongly reinforced by the subtle, but quotidian representations of the nation in daily life: on coins, bills and stamps, in sporting events, by the unnoticed presence of the national flag, and in the division between domestic and foreign news in the newspapers, among other things. However, Billig himself focuses more on the mechanisms of this banal representation of the nation, than on its actual reception by the population at large. ${ }^{8}$ The omnipresence of the nation in popular culture has also been studied in its commercial aspects. Thus, regarding France there are intriguing studies on the role of Michelin, camembert and champagne in the creation of a French national identity. Not unexpectedly, in these cases, it is also much easier to study the activities and decisions of producers to market their products as essentially French, than the reception by the consumers of this more or less hidden nationalist subtext. ${ }^{9}$ Another innovative sub-field of nationalism studies, which could probably help bring to light the impact of the nation-building process in the private sphere, deals with the different ways men and women were affected when becoming integrated into the nation. In general, women were addressed as mothers and wives, rather than as active citizens. ${ }^{10}$

Most existing studies still concentrate on the role of the (often diverse and conflicting) national elites in the nation-building process. Since the 1990s, however, it has become increasingly clear that when studying the construction of national identities, not only the national level must be taken into account, but also the regional and the local levels. Scholars, such as Peter Sahlins, Celia Applegate, Anne-Marie Thiesse, Alon Confino and others, have persuasively argued that regions (in Western European countries) did not just passively accept a modern nation-building policy imposed on them by national elites. The inhabitants of the provinces often played an active role in stimulating national awareness at the local level, while trying to influence the collective self-image that was promoted. Moreover, towards the end of the nineteenth century, regional activists played a decisive role in spreading a more diversified and folkloric national identity to the inhabitants of the provinces. Therefore, regional identities only became more closely defined around the turn of the century. ${ }^{11}$ Various case studies of major cities have made clear that the construction of territorial identity in an urban environment closely mirrored what was happening in the more rural provinces. ${ }^{12}$ At the same time, regional studies on various parts of Austria-Hungary have shown that local, regional, national and imperial identities interacted in a similar, albeit slightly more complex way in Central and Eastern Europe. ${ }^{13}$ Nevertheless, in almost all of these studies attention is still primarily focused on the role of the urban and provincial elites, which again partly has to do with the nature and availability of primary sources. 
The last few years the nation has not only been studied from a local or regional point of view, but its imperial dimension has also become an object of analysis. This way the traditional division between European and colonial history, and between multi-ethnic empires and nation-states is beginning to dissolve with fascinating results. Thus, it has been shown that the career and business opportunities of the British and French empires could have an integrative role in the motherland, providing an attractive outlet to ambitious young men in Scotland, the Provence or Brittany. In Russia, the Ottoman Empire and the Hungarian part of the Austrian Empire elites tried to strengthen the national identities of the core areas, whereas developments in the colonies could have important effects on the nation-building process in the metropolitan areas. For instance, when proclaiming the constitution of 1812 that was meant to end royal absolutism in Spain, Spanish politicians defined national citizenship and suffrage rights in such a way that the representatives of the colonies would not have the majority in the Cortes, while towards the end of the century Cuban claims for Home Rule stimulated Catalan demands for autonomy at home. ${ }^{14}$

\section{Methodological nationalism}

Although the geographical focus of nationalism studies has already been broadened by including the local, regional and imperial perspectives, at present the overwhelming majority of recent investigations consists of case studies that focus on a particular aspect or period within one imperial, national, regional or local context. While the focal point may be different, these studies generally take one state or national movement as their frame of reference and as such they implicitly present the history of Europe as a collection of (isolated) national histories. Theoretical studies, on the contrary, generally adopt a global framework and a rather abstract approach; as a result, they cannot take into account the detailed findings of most case studies. Historical overviews of the rise and evolution of nationalism in Europe that try to integrate at least some of the results from these recent studies are still rare. ${ }^{15}$ Possibly more problematic is the lack of comparative studies based on primary sources, especially when we consider that nearly all historians now admit that there are many striking parallels between the rise and development of nationalist sentiments all over Europe. Consequently, as Umut Özkirimli rightly asserts at the end of his useful Theories of Nationalism, there is an urgent need for 'theoretically informed comparative histories'. 16 Apart from the few exceptions where two or a few countries are compared, there are only a few edited volumes that intend to provide a comparative perspective, yet almost all contributions still deal exclusively with single national cases. ${ }^{17}$

However, the shortage of comparative studies is not the only problem, the same applies to the implicit methodological nationalism of nationalism studies. The term 'methodological nationalism' has recently come into use within the social sciences. In a pioneering article published in 2002, Andreas Wimmer and Nina Glick Schiller systematically dissect the methodological nationalism of their discipline by arguing that classic sociological theory not only downplays the role of nationalism as something of the past, but that sociologists generally equate society with national society. In other words, "nationally bounded societies are taken to be the naturally given entities to study'. Although within the modernist consensus, specialists in the field of nationalism studies no longer see nations as a natural given, they generally adhere to a third variant of methodological nationalism discerned by Wimmer and Glick Schiller: 'the reduction of the analytical focus to the boundaries of the nation state'. ${ }^{18}$

Since most historians of nationalism still limit their field of investigation to one national context, the various stages of the nation-building project are still generally analysed along national lines. Outside influences and external actors are generally ignored, while major 
historical events that particularly concerned the examined country or nation, such as revolutions or wars, are seen as crucial turning points. Thus, a starting (or turning) point for French nationalism is the French Revolution, while accounts of German nationalism generally begin with the Wars of Liberation. Moreover, as Charlotte Tacke makes clear, nationalism studies still generally operate within a specific national historiographical tradition. As a result, following Michelet and Renan, in France the focus has mainly been on citizenship and political nationalism, while largely ignoring expressions of cultural nationalism, whereas in Germany most authors - in the tradition of Herder and Fichte - have studied expressions of cultural or ethnic nationalism. ${ }^{19}$ This methodological nationalism is even reinforced by using concepts that only apply to one national case, such as Heimat in Germany, the Risorgimento in Italy, regeneracionismo in Spain, laicite in France, pillarization in the Netherlands and the idea of the frontier in the United States.

In a similar way, the creation of better defined and delimited idiosyncratic regional identities at the end of the nineteenth century have usually been explained depending on the particular circumstances in each country. Thus, Anne-Marie Thiesse has argued that the need to reflect on one's collective identity was particularly acute in France after the disastrous war against Prussia in 1870-1871. Regional rootedness increasingly became an important topic as the international position of France - marked by military failures and the rise of new economic powers - declined. ${ }^{20}$ Similarly, in the case of Spain, scholars argue that the disastrous defeat of the Spanish-American War of 1898 caused a nation-wide identity crisis that strongly favoured the regional movements. ${ }^{21}$ In Germany, it was victory in the FrancoPrussian War and the subsequent national unification in 1871 that were seen as a similar turning point. ${ }^{22}$ If we accept these arguments, then the different stages of the nation-building process are marked by major political events that occurred in each country at a different time.

These same authors also acknowledge that more general transnational factors may have played a role in the formation of regional identities. In their studies, the rise of regionalism is commonly understood as a new collective self-awareness, which was made possible by the erosion of traditional structures of provincial society during the process of social and economic modernisation and the subsequent democratisation of the local public sphere. ${ }^{23}$ Therefore, they present the rise of a new phase in the construction of national or regional identities as depending on the arrival or acceleration of the general process of modernisation in a certain area, while they only examine the activities of actors who are living within the boundaries of the region or nation. This way, possible trans-border influences and international transfers remain hidden from view. ${ }^{24}$

In fact, this is remarkable, since in many regions the view from abroad often clashed radically with the collective self-image locals held of themselves, and which they deemed most appropriate to attract attention at the national level. In Andalusia, for instance, foreigners were primarily interested in the remains of the Islamic civilisation of Al-Andalus and in the 'savage' flamenco dances of local gypsies. Yet, most well-educated Andalusians preferred to identify themselves as 'civilised' citizens of an essentially modern and/or Catholic society, while glorifying the medieval Reconquista as a national crusade to liberate Spain from the Moorish occupation. ${ }^{25}$ In other peripheral regions local inhabitants interested in the nationbuilding project also often emphasised the contribution of their region to the nation's past glories and current progress, while foreigners appreciated these regions particularly for their picturesque and exotic aspects. Nevertheless, in the long run the view from abroad could be very influential, and many regional stereotypes created by foreigners would even have a substantial impact on the national self-image. Thus, during the twentieth century, flamenco slowly became accepted as an indissoluble part of the Andalusian and Spanish cultural patrimony, ${ }^{26}$ and in 2010 it was even included in Unesco's list of the Intangible Cultural Heritage of Humanity. 


\section{Tourism and the construction of territorial identities}

Some scholars have already acknowledged that outsiders or foreigners have played an important role in the creation of national identities. Foreigners can assume the position of enemy or rival, to which the national identity is opposed. This is particularly true in periods of strong rivalry or war. At the end of the nineteenth and the beginning of the twentieth century, for example, French identity was largely defined as essentially non-German and vice-versa. ${ }^{27}$

Foreigners can also assume the role of observer, producing their own interpretations of a particular nation or region. This could take the form of novels, plays, travel accounts, operas, essays or scientific studies. Especially when power-relations between observers and the observed are unequal (e.g. in a colonial setting), then the gaze of the outside observer can be intimidating and can significantly influence the self-perception of the other. Following Edward Said's influential Orientalism (1978), this process of 'othering' has been a major topic in post-colonial studies. Nonetheless, most scholars nowadays agree that even where the power balance is uneven, in most cases there is room for negotiation or redefinition. ${ }^{28}$ Surprisingly, in a Western context studies concerned with the view from abroad - also known under the label of imagology - generally concentrate on the production-side and do not explore the impact of these foreign images on the host societies. ${ }^{29}$

Another promising approach is proposed by Joep Leerssen. By focusing on transborder transfers, he aims to analyse the international intellectual networks that produced and diffused the ideas and practices of nineteenth-century cultural nationalism. ${ }^{30}$ Although the role of tourism is still largely ignored in more general studies on the construction of national identities, probably the most important external influence on the nation-building process, especially in the long run, has been that of the traveller or tourist.

During the last few decades, there has been a rapidly growing interest in the history of tourism. The economic impact of tourism and the institutional support it received have already been explored relatively well. In more culturally-oriented studies tourism was often seen as a superficial and vulgar mass phenomenon compared to the refined taste and the adventurous attitude of the individual traveller. Nonetheless, academics also began to pay attention to the motives and attitudes of the tourists themselves, by analysing the origin and evolution of the tourist gaze, with its longing for authenticity, exoticism and spectacle. ${ }^{31}$ More recently, the impact of tourism on host societies, including the influence of travellers and tourists on the image of a nation or region, has become an object of inquiry. ${ }^{32}$ This is also true of efforts, both by authorities and more commercial actors, to paint a positive image of a city, region or country - also known as city- or nation-branding - in order to attract tourists. ${ }^{33}$

The role of tourism in the creation of national and regional identities has been demonstrated for various parts of the United States and Western Europe. Interestingly, scholars made clear that not only politicians and intellectuals were key in the construction of territorial identities, but that economic actors and commercial motives also played a crucial role. Already in 1995 Dana Brown showed how the rise of middle class tourism turned the economically backward New England into a charming and nostalgic tourist destination, with beautiful fishing villages, rustic cottages and a peaceful countryside, thus profoundly affecting the region's identity. The role of intellectuals, businessmen, and local authorities in stimulating tourism to Yellowstone, the world's first national park, and the city of New York has also been examined. The rapid growing influx of visitors converted these rather exceptional places into national icons. In the case of Yellowstone this even involved the removal of Native Americans in order to produce the empty wilderness that matched the foundational myth of the white settlers. ${ }^{34}$ In Great Britain, most scholars directed their attention to the impact of tourists on the creation of a Scottish collective identity. Thus, the 
social anthropologist Jane Nadel-Klein, basing her analysis on archival research and interviews, gives an intimate picture of the transformation of a number of decaying fishing villages into typical Scottish tourist destinations, while Katherine Haldane Grenier examines how travel accounts and guidebooks profoundly influenced Scottish identity. ${ }^{35}$ Particularly interesting is Eric G.E. Zuelow's Making Ireland Irish. In this book, he presents a detailed account of the efforts by the official tourist organizations and all kinds of private initiatives, such as the Guinness Brewing Company, to stimulate tourism in the young Irish republic. As a result, Ireland was made more Irish. Thus, a 'Tidy Towns and Villages Competition', which was first launched in 1958, succeeded in transforming many drab and crumbling hamlets into attractive and tidy 'typically Irish' villages, with picturesque houses painted in pastel colours. ${ }^{36}$ Similar studies on Sweden, Germany, France and Spain have shown that comparable processes occurred there as well. ${ }^{37}$

However, the authors of these studies still primarily focus on domestic tourism. This, in general, is quite different in similar investigations of non-Western tourist destinations, where the impact of foreign visitors has been the preferred object of the analysis. Thus, in a pioneering study published in 1989, Adrian Vickers showed how foreign residents and visitors shaped the image of the Indonesian island Bali as an exotic, tropical paradise, while 'inventing' all kinds of native traditions, arts and crafts. ${ }^{38}$ Social anthropologists have also begun to investigate the impact of international tourism on small communities in Asia, Africa and South and Central America. ${ }^{39}$ Yet up until now European case studies have only occasionally paid attention to the influence of foreign tourists. ${ }^{40}$ By taking into account the role of both foreign and domestic tourists in the construction and diffusion of regional and national identities we can get a more encompassing understanding of the nation-building process in various parts of Europe.

\section{Overcoming methodological nationalism}

The analysis of the impact of foreign tourists on the nation-building process in various countries can be a good tool for overcoming methodological nationalism. My hypothesis is that the impact of tourism had its own dynamic and that various transnational patterns and mechanisms - which remained largely invisible in the traditional approach - can be detected that strongly influenced the construction of regional and national identities. In order to also pay attention to the role of wider strata of the population and both the production and consumption of collective identities, it is expedient to focus on a few small communities in various countries that already began to attract a considerable number of travellers during the nineteenth century and for which as a consequence sufficient primary sources are available to conduct a comparative study of the impact of foreign visitors on the local process of territorial identity construction.

These local communities are the arenas in which the outside influences of an international, national and regional level came together and demanded a local response. Foreign travellers and tourists generally were looking for picturesque and authentic images and original experiences. The central state and national elites were mostly preoccupied with the nation-building process: educating the local population to become dutiful citizens with a sufficient knowledge of the national standard language and the nation's history and geography. Often, nevertheless, there were clashes between progressives and conservatives over the exact national identity that had to be adopted. Demands were also made at a regional level. In Bavaria, for example, on the occasion of the wedding of Crown Prince Maximilian during the Munich Oktoberfest of 1842, the Bavarian government asked each district to send young couples of 'flawless behaviour' dressed in provincial costumes who could get married on the same day. In many of the districts it was more difficult to find traditional Bavarian 
costumes, some of which had to be (re-) invented for the occasion, than to trace reputable couples willing to marry. ${ }^{41}$ Regional authorities were not the only ones to make demands; the same was true for regional elites. In Brittany regional elites tried to stimulate tourism by publishing regional travel guides and the magazine La Bretagne touristique (1922-1939), while at the same time contributing to the region-building process by organising the construction and decoration of a Breton pavilion at the World Fairs in Paris in 1925 and 1937, for which local cooperation was required. ${ }^{42}$

It seems that attracting visitors, which was in the interest of local hotel owners, inn keepers, guides and others involved in the tourist business, was a rather neutral goal. However, this was not always the case. Especially the growing presence of large numbers of tourists at traditional (religious) events, such as Pardons in Brittany, the Passion Plays in the Bavarian village of Oberammergau or the Holy Week in Andalusia, could easily cause friction. ${ }^{43}$ In addition, the outright invention of new festivals intended for tourists, such as the one held in Pont-Aven in 1905, with their 'staged authenticity' or 'performed heritage', often led to controversies. ${ }^{44}$ Other debates were held over the foundation of local museums and the appropriate choice of exhibits, the demolition or conservation of characteristic buildings, such as the Jewish quarter in Toledo, the modernisation of certain parts of a town or village, such as the construction of the Gran Vía through the old parts of Granada. These discussions, which concerned issues that directly touched upon the local self-image, were often more intense than at the national level since they directly affected private interests and could become enmeshed with local power struggles and personal rivalries. ${ }^{45}$ All these manifold demands, both from tourists and national and regional authorities and elites, had to be met and reconciled at the local level.

Although until the 1960s foreign tourism was still an elite affair, the focus on small communities makes it possible to also map the reaction of wider strata of the local population. The response to both the nation-building process and the role of (foreign) tourism can be divided into positive, neutral and negative. Social anthropologists, who investigated the impact of foreign tourists on local communities, have already distinguished various forms of adjustment, especially to protect the population from outside influences. Whereas in many places both elites and wider groups are not averse to organizing 'heritage performances' for visitors at the front stage, they generally prefer to protect the 'back stage' from the tourist gaze. This can be done by maintaining clear boundaries, but also by more negative reactions such as retreating, resisting and protesting. ${ }^{46}$ These categories can also successfully be applied to the local population's response to the nation-building process. Many inhabitants and even members of the local elite, however, were not hostile but largely indifferent to both tourists and nation-builders. A third response was welcoming and positive. This could result in enthusiastically organising or participating in a new national holiday or touristic festival, in protecting or making accessible the local material and immaterial heritage, or in 'revitalizing' old traditions.

The foreign impact on the process of collective identity construction in these small communities can best be studied by looking at significant debates on the role of tourism and by examining concrete encounters between inhabitants and visitors. By using a wide variety of primary sources - the press and archives of relevant authorities and associations for the debates, and travel writings, sketches, photos, diaries and interviews for the encounters - it will be possible to avoid a one-sided focus on local intellectual and political elites, while examining the interaction between the production of new collective identities and their active consumption by the local population and (foreign) tourists. By integrating the influence of visitors from abroad, we will get a more encompassing and nuanced picture of the way the local population transformed their own face-to-face communities into part of the new and wider 'imagined communities' of both their nation and region, while unravelling some of the 
underlying transnational patterns and mechanisms in the construction and diffusion of national and regional identities

\footnotetext{
${ }^{1}$ I would like to thank my colleagues and students of the MA Political Culture and National Identities at Leiden University for their feedback on a first draft of this article.

${ }^{2}$ Gellner, Nations and Nationalism, Anderson, Imagined Communities; Hobsbawm and Ranger (eds.), Invention of Tradition.

${ }^{3}$ One of the first of Smith's many books on this topic is Ethnic Origins of Nations; see for a similar recent view Gat, Nations.

${ }^{4}$ Özkirimli, Contemporary Debates on Nationalism.

${ }^{5}$ Weber, Peasants into Frenchmen. A slightly different approach in Mosse, The Nationalization of the Masses.

${ }^{6}$ For an overview see: Cabo and Molina, 'Long and Winding Road'.

${ }^{7}$ Van Ginderachter and Beyen, Nationhood from below. Possible exceptions are letters from soldiers during wartime. See: Ziemann, War Experiences in Rural Germany; Núñez Seixas, ¡Fuera el invasor!

${ }^{8}$ Billig, Banal Nationalism. See also Edensor, National Identity, Popular Culture.

${ }^{9}$ Boisard, Le Camembert; Harp, Marketing Michelin; Guy, When Champagne became French. For Germany see also Schramm, Konsum und regionale Identität.

${ }^{10}$ Blom, Hagemann and Hall (eds.), Gendered Nations; Reagin, Sweeping the German Nation; Vlossak, Marianne or Germania.

${ }^{11}$ Sahlins, Boundaries; Applegate, Nation of Provincials; Thiesse, Écrire la France; Ford, Creating the Nation in Provincial France; Confino, Nation as a Local Metaphor; Baycroft, Culture, Identity and Nationalism; Forcadell Álvarez and Romeo Mateo, eds., Provincia y nación; Augusteijn and Storm, (eds.) Region and State in Nineteenth-Century Europe.

${ }^{12}$ Jenkins, Provincial Modernity; Michonneau, Barcelone; Zimmer, Remaking the Rhythms of Life.

${ }^{13}$ Stauter-Halsted, Nation in the Village; King, Budweisers; Zahra, Kidnapped Souls.

${ }^{14}$ Berger and Miller, 'Nation-Building and Regional Integration'; Leonhard and von Hirschhausen, Empires und Nationalstaaten; Augsteijn and Storm (eds.), Region and State; Núnez, 'Nation-Building and Regional Integration'.

${ }^{15}$ Thiesse, Création des identités nationales; Leerssen, National Thought in Europe; Zimmer, Nationalism in Europe; Kramer, Nationalism in Europe and America.

${ }^{16}$ Özkirimli, Theories of Nationalism, 233. See also: Leerssen, 'Nationalism and the Cultivation of Culture' and Núñez, 'Nations and Nationalism in Europe'.

${ }^{17}$ Exceptions are Hroch, Social Preconditions; Greenfeld, Nationalism. Broad-ranging collective projects are Baycroft and Hewitson (eds.), What is a Nation and the many volumes from the ESF research programme Representations of the Past: The Writing of National Histories in Europe such as Berger and Lorenz (eds.), Nationalizing the Past.

${ }^{18}$ Wimmer and Glick Schiller, 'Methodological Nationalism', 221 and 225.

${ }^{19}$ Tacke, 'National Symbols'; Hewitson, 'Conclusion'.

${ }^{20}$ Thiesse, Écrire la France, 12-13 and 240-243.

${ }^{21}$ Núñez, 'The Region as Essence'.

${ }^{22}$ Applegate, Nation of Provincials, 13 and Confino, Nation as a Local Metaphor, 134 and 126.

${ }^{23}$ Confino, Nation as a Local Metaphor, 98. See also: Ford, Creating the Nation; Stauter-Halsted, Nation in the Village and Guy, When Champagne became French.

${ }^{24}$ The rise of regionalism can also be explained as an international trend that was rapidly absorbed in most parts of Europe: Storm, Culture of Regionalism.

${ }^{25}$ Méndez Rodríguez, La imagen de Andalucía; Álvarez Junco, Mater Dolorosa, 217-221.

${ }^{26}$ Although probably not all Spaniards have internalised this view.

${ }^{27}$ See for example Jeismann, Vaterland der Feinde; Triandafyllidou, 'National Identity'.

${ }^{28}$ It was also generally assumed that nationalism in the colonial world was a Western import, or a 'derivative discourse'. However, this view has been criticized as too one-sided. See: Chatterjee, Nation and its Fragments; Bayly, Origins of Nationality.

${ }^{29}$ Beller and Leerssen, eds., Imagology; Zacharasiewicz, Imagology revisited.

${ }^{30}$ Leerssen, 'Nationalism and the Cultivation of Culture'. See also his Study Platform on Interlocking Nationalisms: www.spinnet.eu.

${ }^{31}$ Classic studies are MacCannell, The Tourist; Urry, The Tourist Gaze. See for recent historiographical overviews: Walton, 'Prospects in Tourism History'; Kilbride, 'Travel Writing as Evidence'.

${ }^{32}$ See: Koshar, 'What Ought to Be Seen'; Baranowski and Furlough (eds.), Being Elsewhere; Walton, (ed.), Histories of Tourism.
} 


\footnotetext{
${ }^{33}$ Pack, Tourism and Dictatorship; Ward, Selling Places; Dinnie, Nation Branding.

${ }^{34}$ Dona, Inventing New England; Magoc, Yellowstone; Spence, Dispossessing the Wilderness; Blake, How New York became American.

${ }^{35}$ Nadel-Klein, Fishing for Heritage; Grenier, Tourism and Identity.

${ }^{36}$ Zuelow, Making Ireland Irish.

${ }^{37}$ Löfgren, 'Know Your Country'; Hagen, Preservation, Tourism and Nationalism; Murdock, 'Tourist

Landscapes'; Garner, A Shifting Shore; Vincent, L'Intrusion balnéaire; Young, Enacting Brittany; Storm, 'Una España más española'.

${ }^{38}$ Vickers, Bali: A Paradise Created. Most similar studies focus on more recent periods, such as: Boswell, 'Heritage Tourism'; Marschall, 'Making Money with Memories'; Merrill, Negotiating Paradise.

${ }^{39}$ Smith and Brent (eds.), Hosts and Guests Revisited; Gmelch (ed.), Tourists and Tourism; Chambers, Native Tours.

${ }^{40}$ Exceptions are Pes, 'L'invenzione della cucina veneziana'; Young, 'Of Pardons, Loss and Longing'; van Ginkel, 'De verbeelding van "Hollands” vissersvolk'; Méndez Rodríguez et al., Viaje a un Oriente europeo.

${ }^{41}$ Bendix, 'Costumed Identity'.

${ }^{42}$ Couédic, Les Architectes et l'idée bretonne.

${ }^{43}$ Young, Enacting Brittany, 171-215; Waddy, Obberammergau in the Nazi Era.

${ }^{44}$ These concepts are used by MacCannell, The Tourist and Kirshenblatt-Gimblett, Destination Culture, respectively.

${ }^{45}$ Storm, 'Patrimonio local, turismo e identidad nacional'.

${ }^{46}$ Dogan, 'Forms of Adjustment'; Boissevain (ed.), Coping with Tourists, Porter, 'Heritage Tourism'.
}

\section{Bibliography}

Álvarez Junco, J., Mater Dolorosa. La idea de España en el siglo XIX (Madrid: Taurus, 2001).

Anderson, B., Imagined Communities: Reflections on the Origin and Spread of Nationalism (London, Verso, 1983).

Applegate, C., A Nation of Provincials: The German Idea of Heimat (Berkeley: University of California Press, 1990).

Augusteijn, J. and Storm, E. (eds.), Region and State in Nineteenth-Century Europe: NationBuilding, Regional Identities and Separatism (Basingstoke: Palgrave, 2012).

Baranowski, S. and Furlough, E. (eds.), Being Elsewhere: Tourism, Consumer Culture and Identity in Modern Europe and North America (Ann Arbor: University of Michigan Press, 2001).

Baycroft, T., Culture, Identity and Nationalism: French Flanders in the Nineteenth and Twentieth Century (London: Royal Historical Society, 2004).

Baycroft, T. and Hewitson, M. (eds.), What is a Nation? Europe 1789-1914 (Oxford: Oxford University Press, 2006).

Bayly, C., Origins of Nationality in South Asia: Patriotism and Ethical Government in the Making of Modern India (Oxford: Oxford University Press, 1998).

Beller, M. and Leerssen, J. (eds.), Imagology: The Cultural Construction and Literary Representation of National Characters: A Critical Survey (Amsterdam: Rodopi, 2007).

Bendix, R., 'Moral Integrity in Costumed Identity: Negotiating "National Costume" in $19^{\text {th }}$ Century Bavaria', Journal of American Folklore (1998): 133-145.

Berger, S. and Miller, A., 'Nation-Building and Regional Integrations, c. 1800-1914: The Role of Empires', European Review of History/Revue Européenne d'Histoire (2008) 317-330.

Berger, S. and Lorenz, C. (eds.), Nationalizing the Past: Historians as Nation-Builders in Modern Europe (Basingstoke: Palgrave, 2010).

Billig, M., Banal Nationalism (London: Sage, 1995). 
Blake, A.M., How New York became American, 1890-1924 (Baltimore: Johns Hopkins University Press, 2006).

Blom, I., Hagemann, K. and Hall, C. (eds.), Gendered Nations: Nationalisms and Gender Order in the Long Nineteenth Century (Oxford: Berg 2000).

Boisard, P., Le Camembert, mythe national (Paris: Calmann-Lévy, 1992).

Boissevain, J. (ed.), Coping with Tourists : European Reactions to Mass Tourism (Providence: Berghahn, 1998).

Boswell, R., 'Heritage Tourism and Identity in the Mauritian Villages of Chamarel and Le Morne', Journal of Southern African Studies (2005): 283-295.

Brown, D., Inventing New England: Regional Tourism in the Nineteenth Century (Washington: Smithsonian Institute Press, 1995).

Cabo, M. and Molina, F., 'The Long and Winding Road of Nationalization: Eugen Weber's Peasants into Frenchmen in Modern European History (1976-2006)', European History Quarterly (2009): 264-286.

Chambers, E., Native Tours: The Anthropology of Travel and Tourism (Long Grove: Waveland Press, 2010).

Chatterjee, P., The Nation and its Fragments. Colonial and Postcolonial Histories (Princeton: Princeton University Press, 1993).

Confino, A., The Nation as a Local Metaphor: Württemberg, Imperial Germany, and National Memory, 1871-1918 (Chapel Hill: University of North Carolina Press, 1997).

Couédic, D. le, Les Architectes et l'idée bretonne, 1904-1945. D'un renouveau des arts à la renaissance d'une identité (Rennes: Société d'Histoire et d'Archéologie de Bretagne, 1995).

Dinnie, K. (ed.), Nation Branding : Concepts, Issues, Practice (Oxford: Elsevier 2008).

Dogan, H.Z., 'Forms of Adjustment: Sociocultural Impacts of Tourism', Annals of Tourism Research (1989) 237-253.

Edensor, T., National Identity, Popular Culture and the Everyday Life (Oxford and New York: Berg, 2002).

Forcadell Álvarez, C., and Romeo Mateo, M.C. (eds.), Provincia y nación. Los territorios del liberalismo (Zaragoza: Institución Fernando el Católico, 2006).

Ford, C., Creating the Nation in Provincial France: Religion and Political Identity in Brittany (Princeton: Princeton University Press, 1993).

Garner, A., Shifting Shore: Locals, Outsiders, and the Transformation of a French Fishing Town, 1823-2000 (Ithaca: Cornell University Press, 2004).

Gat, A., with Yakobson, A., Nations: The Long History and Deep Roots of Political Ethnicity and Nationalism (Cambridge: Cambridge University Press, 2013).

Gellner, E., Nations and Nationalism (Ithaca: Cornell University Press, 1983).

Ginkel, R. van, 'De verbeelding van "Hollands" vissersvolk. Visuele cultuur en het folkloristische cliché van Marken en Volendam', Sociologie (2009): 2-26.

Gmelch, S.B. (ed.), Tourists and Tourism: A Reader (Long Grove: Waveland Press 2004).

Greenfeld, L., Nationalism: Five Roads to Modernity (Cambridge: Harvard University Press, 1992).

Grenier, K. H., Tourism and Identity in Scotland, 1770-1914: Creating Caledonia (Aldershot: Ashgate, 2005).

Guy, K. M., When Champagne became French: Wine and the Making of National Identity (Baltimore: Johns Hopkins University Press, 2007).

Hagen, Joshua, Preservation, Tourism and Nationalism: The Jewel of the German Past (Aldershot: Ashgate, 2006). 
Harp, S. L., Marketing Michelin: Advertising and Cultural Identity in Twentieth-Century France (Baltimore: Johns Hopkins University Press, 2001).

Hewitson, M. 'Conclusion' in Baycroft, T. and Hewitson, M. (eds.), What is a Nation? Europe 1789-1914 (Oxford: Oxford University Press, 2006), 312-355.

Hobsbawm, E., and Ranger, T. (eds.), The Invention of Tradition (Cambridge: Cambridge University Press, 1983).

Hroch, M., Social Preconditions for National Revival in Europe: A Comparative Analysis of the Social Composition of Patriotic Groups among the Smaller European Nations (1969; Cambridge: Cambridge University Press, 1985)

Jeismann, M., Das Vaterland der Feinde: Studien zum nationalen Feindbegriff und Selbstverständnis in Deutschland und Frankreich 1792-1918 (Stuttgart: Klett-Cotta, 1992).

Jenkins, J., Provincial Modernity: Local Culture and Liberal Politics in Fin-de-Siècle Hamburg (Ithaca: Cornell University Press, 2003).

Kilbride, D., 'Travel Writing as Evidence with Special Attention to Nineteenth-Century Anglo-America', History Compass (2011): 339-350.

King, J., Budweisers into Czechs and Germans: A Local History of Bohemian Politics, 18481948 (Princeton: Princeton University Press, 2002).

Kirshenblatt-Gimblett, B., Destination Culture: Tourism, Museums and Heritage (Berkeley: University of California Press, 1998).

Koshar, R., "'What Ought to Be Seen": Tourists' Guidebooks and National Identities in Modern Germany and Europe', Journal of Contemporary History (1998): 323-340.

Kramer, L.S., Nationalism in Europe and America: Politics, Cultures and Identities since 1775 (Chapel Hill: University of North Carolina Press, 2011).

Leerssen, J., National Thought in Europe: A Cultural History (Amsterdam: Amsterdam University Press, 2006).

Leerssen, J., 'Nationalism and the Cultivation of Culture', Nations and Nationalism (2006): 559-578.

Leonhard, J. and von Hirschhausen, U., Empires und Nationalstaaten im 19. Jahrhundert (Göttingen: Vandenhoeck \& Ruprecht, 2009).

Löfgren, O., 'Know Your Country: A Comparative Perspective on Tourism and Nation Building in Sweden' in: Baranowski, S. and Furlough, E. (eds), Being Elsewhere: Tourism, Consumer Culture, and Identity in Modern Europe and North America (Ann Arbor: University of Michigan Press, 2001), 137-154.

MacCannell, D., The Tourist: A New Theory of the Leisure Class (New York: Schocken Books, 1976).

Magoc, C.J., Yellowstone: The Creation and Selling of an American Landscape, 1870-1903 (Albuquerque: University of New Mexico Press, 1999).

Marschall, S., 'Making Money with Memories: The Fusion of Heritage, Tourism and Identity Formation in South Africa', Historia (2005): 103-122.

Méndez Rodríguez, L., La imagen de Andalucía en el arte del siglo XIX (Seville: Centro de Estudios Andaluces, 2008).

Méndez Rodríguez, L., Plaza Orellana, R., and Zoido Naranjo A., Viaje a un Oriente europeo: Patrimonio y turismo en Andalucía (1800-1929) (Sevilla: Centro de Estudios Andaluces, 2011).

Merrill, D., Negotiating Paradise: U.S. Tourism and Empire in Twentieth-Century Latin America (Chapel Hill: University of North Carolina Press, 2009).

Michonneau, S., Barcelone: Mémoire et identité, 1830-1930 (Rennes, Presses Universitaires de Rennes, 2007). 
Mosse, G.L., The Nationalization of the Masses: Political Symbolism and Mass Movements in Germany from the Napoleonic Wars through the Third Reich (New York: Fertig, 1975).

Murdock, C.E., 'Tourist Landscapes and Regional Identities in Saxony, 1878-1938', Central European History (2007): 589-621.

Nadel-Klein, J., Fishing for Heritage: Modernity and Loss Along the Scottish Coast (Oxford: Berg, 2003).

Núñez, X.M., 'The Region as Essence of the Fatherland: Regionalist Variants of Spanish Nationalism (1840-1936)', European History Quarterly (2001): 483-518.

Núñez Seixas, X.M., ¡Fuera el invasor! Nacionalismos y movilización bélica durante la Guerra Civil española (1936-1939) (Madrid: Marcial Pons, 2006).

Núñez, X.M., 'Nations and Nationalism in Europe: Transnational Reflections', European History Quarterly (2010): 669-684.

Núñez, X.M., 'Nation-Building and Regional Integration: The Case of the Spanish Empire' in: Berger, S. and Miller, A. (eds.), Nationalizing Empires (Budapest: Central European University Press, in press).

Özkirimli, U., Contemporary Debates on Nationalism: A Critical Engagement (Basingstoke: Palgrave, 2005).

Özkirimli, U., Theories of Nationalism: A Critical Introduction (Basingstoke: Palgrave, 2000).

Pack, S., Tourism and Dictatorship: Europe's Peaceful Invasion of Franco’s Spain (Basingstoke: Palgrave, 2006).

Pes, L., 'L'invenzione della cucina veneziana. Consumi, turismo e identità cittadina', Memoria e Ricerca (2006): 47-62.

Porter, B.W., 'Heritage Tourism: Conflicting Identities in the Modern World' in: Graham, B. and Howard, P. (eds.), The Ashgate Research Companion to Heritage and Identity (Farnham: Ashgate, 2008), 267-282.

Reagin, N.R., Sweeping the German Nation: Domesticity and National Identity in Germany, 1870-1945 (Cambridge: Cambridge University Press, 2008).

Sahlins, P., Boundaries: The making of France and Spain in the Pyrenees (Berkeley: University of California Press, 1989).

Said, E., Orientalism (New York: Pantheon, 1978).

Schramm, M., Konsum und regionale Identität in Sachsen 1880-2000. Die Regionalisierung von Konsumgütern im Spannungsfeld von Nationalisierung und Globalisierung (Stuttgart: Steiner, 2002).

Smith, A. D., The Ethnic Origin of Nations (Oxford: Blackwell, 1986).

Smith, V.L. and Brent, M. (eds.), Hosts and Guests Revisited: Tourism Issues of the $21^{\text {st }}$ Century (New York: Cognizant Communication Corporation, 2001).

Spence, M.D., Dispossessing the Wilderness: Indian Removal and the Making of National Parks (Oxford: Oxford University Press, 2000).

Stauter-Halsted, K., The Nation in the Village: The Genesis of Peasant National Identity in Austrian Poland, 1848-1914 (Ithaca: Cornell University Press, 2001).

Storm, E., The Culture of Regionalism: Art, Architecture and International Exhibitions in France, Germany and Spain, 1890-1939 (Manchester: Manchester University Press, 2010).

Storm, E., 'Una España más española. La influencia del turismo en la imagen nacional' in: Moreno Luzón, J. and Núñez Seixas, X.M. (eds.), Ser españoles. Imaginarios nacionalistas en el siglo XX (Barcelona: RBA, 2013), 530-560. 
Storm, E., 'Patrimonio local, turismo e identidad nacional en una ciudad de provincias: Toledo a principios del siglo XX', Hispania (2013): 349-377.

Tacke, C., 'National Symbols in France and Germany in the Nineteenth Century' in Haupt, H.G., Müller, M. and Woolf, S. (eds.), Regional and National Identities in Europe in the XIXth and XXth Centuries (The Hague: Kluwer, 1998) 411-436.

Thiesse, A.-M., Écrire la France. Le Mouvement littéraire régionaliste de langue française entre la Belle Epoque et la Libération (Paris: PUF, 1991).

Thiesse, A.-M., La Création des identités nationales: Europe XVIIIe-XXe siècle (Paris: Seuil, 1999).

Triandafyllidou, A., 'National Identity and the "Other"', Ethnic and Racial Studies (1998): 593-612.

Urry, J., The Tourist Gaze: Leisure and Travel in Contemporary Societies (London: Sage, 1990).

Van Ginderachter, M. and Beyen, M. (eds.), Nationhood from Below: Europe in the Long Nineteenth Century (Basingstoke: Palgrave, 2012).

Vickers, B., Bali: A Paradise Created (Berkeley: Periplus, 1989).

Vincent, J., L'Intrusion balnéaire: Les Populations littorales bretonnes et vendéennes face au tourisme (1800-1945) (Rennes: Presses Universitaires de Rennes, 2008).

Vlossak, E., Marianne or Germania? Nationalizing Women in Alsace, 1870-1946 (Oxford: Oxford University Press, 2010).

Waddy, H., Obberammergau in the Nazi Era: The Fate of a Catholic Village in Hitler's Germany (Oxford: Oxford University Press, 2010).

Walton, J.K. (ed.), Histories of Tourism: Representation, Identity and Conflict (Clevedon: Channel View Publications, 2005).

Walton, J.K. 'Prospects in Tourism History: Evolution, State of Play and Future Developments', Tourism Management (2009) 783-793.

Ward, S.V., Selling Places: The Marketing and Promotion of Towns and Cities, 1850-2000 (New York: Routledge, 1998).

Weber, E., Peasants into Frenchmen: The Modernization of Rural France (Stanford: Stanford University Press, 1976).

Wimmer, A. and Glick Schiller, N., 'Methodological Nationalism and the Study of Migration', European Journal of Sociology (2002): 217-240.

Young, P., 'Of Pardons, Loss and Longing: The Tourist's Pursuit of Originality in Brittany, 1890-1935', French Historical Studies (2007): 269-304.

Young, P., Enacting Brittany: Tourism and Culture in Provincial France, 1871-1939

(Farnham: Ashgate, 2012).

Zacharasiewicz, W., Imagology revisited (Amsterdam: Rodopi, 2010).

Zahra, T., Kidnapped Souls: National Indifference and the Battle for Children in the Bohemian Lands (Ithaca: Cornell University Press, 2011).

Ziemann, B., War Experiences in Rural Germany: 1914-1923 (Berg: Oxford, 2007).

Zimmer, O., Nationalism in Europe, 1890-1940 (Basingstoke: Palgrave, 2003).

Zimmer, O., Remaking the Rhythms of Life: German Communities in the Age of the NationState (Oxford: Oxford University Press, 2013).

Zuelow, E.G.E., Making Ireland Irish: Tourism and National Identity since the Irish Civil War (Syracuse: Syracuse University Press, 2009). 